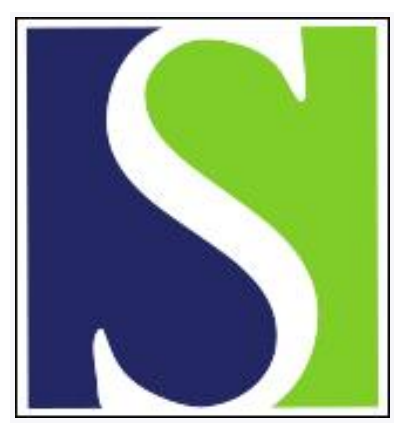

Scand J Work Environ Health 1983;9(2):94-102

https://doi.org/10.5271/sjweh.2417

Issue date: Apr 1983

Reproductive-toxicologic assessment of the epoxides ethylene oxide, propylene oxide, butylene oxide, and styrene oxide.

by Hardin BD, Niemeier RW, Sikov MR, Hackett PL

This article in PubMed: www.ncbi.nlm.nih.gov/pubmed/6648426

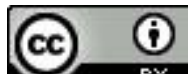




\title{
Reproductive-toxicologic assessment of the epoxides ethylene oxide, propylene oxide, butylene oxide, and styrene oxide
}

\author{
by Bryan D Hardin, MS, ${ }^{1}$ Richard W Niemeier, PhD, ${ }^{1}$ Melvin R Sikov, PhD, ${ }^{2}$ \\ Patricia L Hackett, PhD
}

\begin{abstract}
HARDIN BD, NIEMEIER RW, SIKOV IMR, HACKETT PL. Reproductive-toxicologic assessment of the epoxides ethylene oxide, propylene oxide, butylene oxide and styrene oxide. Scand $j$ work environ health 9 (1983) 94-102. Ethylene oxide (CAS no 75-21-8), propylene oxide (CAS no 75-56-9), butylene oxide (CAS no 106-88-7), and styrene oxide (CAS no 96-09-3) were tested for teratogenic activity by inhalation exposure of rats and rabbits. Ethylene oxide and propylene oxide were tested at only one concentration in both species (150 ppm for ethylene oxide and $500 \mathrm{ppm}$ for propylene oxide). Butylene oxide was tested at 250 and $1,000 \mathrm{ppm}$ in both species, while styrene oxide was tested at $100 \mathrm{ppm}$ in rats and 15 and $50 \mathrm{ppm}$ in rabbits. For each of these four epoxides, the acute toxicity was similar for pregnant and nonpregnant rats. Styrene oxide was the most toxic in both species, and rabbits were more sensitive than rats. Rats exposed to propylene oxide for $7 \mathrm{~h} / \mathrm{d}, 5 \mathrm{~d} /$ week for three weeks before breeding had a significant reduction in the number of corpora lutea. Fetal mortality was not increased, but significantly fewer mated rats were found pregnant following gestational exposure to styrene oxide, a finding suggesting preimplantation loss. In rabbits exposed to styrene oxide, the number of resorptions per litter was increased in a concentrationrelated manner, but differences were not statistically significant. Fetal examinations revealed evidence of fetotoxicity with all four epoxides. There was no overt teratogenic activity, but a number of minor morphologic aberrations were detected.
\end{abstract}

Key terms: 1,2-epoxybutane, 1,2-epoxyethane, epoxyethylbenzene, 1,2-epoxypropane, ethyloxirane, inhalation teratogenesis, methyloxirane, oxirane.

Ethylene oxide, propylene oxide, butylene oxide, and styrene oxide are widely used in large volumes as intermediates in organic chemical synthesis. Ethylene oxide and propylene oxide are also used as chemical fumigants or as sterilants for medical and scientific supplies, foodstuffs, drugs, and other materials such as motor oil, paper, and furniture. In addition to its use in chemical synthesis, styrene oxide is used as a reactive diluent in epoxy

1 Division of Biomedical and Behavioral Science, National Institute for Occupational Safety and Health, Cincinnati, Ohio, United States.

2 Battelle Pacific Northwest Laboratories, Richland, Washington, United States.

Reprint requests to: $\mathrm{Mr} \mathrm{BD}$ Hardin, Robert A Taft Laboratories, 4676 Columbia Parkway, Cincinnati, OH 45226, USA. resins.

Ehrenberg \& Hussain (1) reviewed the literature available on the mutagenicity of 1,2-epoxides up to 1978; they found evidence that all four epoxides under consideration in the present communication are mutagenic in various test systems. The International Agency for Research on Cancer's review (4) of the data on the potential carcinogenicity of ethylene oxide, propylene oxide, and styrene oxide concluded that only propylene oxide had shown limited evidence of carcinogenicity in animals. All three of these epoxides are currently undergoing chronic toxicity testing.

Very little has been published on the developmental toxicity of these epoxides. Snellings et al (7) reported no developmental defects when pregnant rats were ex- 
posed to $0,10,33$, or 100 ppm $(0,18,60$, or $180 \mathrm{mg} / \mathrm{m}^{3}$, respectively) of ethylene oxide on days $6-15$ of gestation, although the body weights of fetuses were reduced at $100 \mathrm{ppm}$. In a reproduction study, Snellings et al (7) exposed both male and female rats to ethylene oxide for 12 weeks before breeding and continued exposing females through day 19 of gestation. The females exposed at $100 \mathrm{ppm}$ had a longer period of gestation, a reduced fertility index, and significantly fewer pups. Because of concern for the intravenous exposure of humans to ethylene oxide leaching from ethylene oxide-sterilized medical devices, LaBorde \& Kimmel (5) injected pregnant mice intravenously during four 3-d segments of gestation. Ethylene oxide was clearly teratogenic on days $6-8$ of gestation and caused primarily skeletal defects; the frequency of malformations was also increased in groups treated on day $8-10$ and $10-12$.

Recently completed studies have evaluated the reproductive toxicity of ethylene oxide, propylene oxide, butylene oxide, and styrene oxide. Detailed results of these studies are available from the National Institute for Occupational Safety and Health (NIOSH) in a contract report (2) and in a NIOSH technical report (6). Individual reports on each epoxide are being prepared for publication in the open literature. The present report will present only a general overview of the salient changes observed and will concentrate on comparisons between epoxides. As will be shown, the resulting patterns have important implications for the design and interpretation of reproductive and developmental toxicity studies of materials for which repeated occupational or environmental exposure is of concern.

\section{Materials and methods}

Sexually mature female Sprague-Dawley (ethylene oxide \& propylene oxide) or Wistar (butylene oxide \& styrene oxide) rats and New Zealand white rabbits were used. In all studies each group consisted of 23 to 30 artificially inseminated rabbits and 32 to 45 spermpositive rats. The number of litters examined ranged from 15 to 23 rabbits per group and from 28 to 46 rats per group.
Exceptions occurred when maternal mortality was especially high (one rat and two rabbit groups), and in one rabbit group when pseudopregnancies reduced the number of pregnant dams.

Exposures were conducted in stainless steel dynamic inhalation chambers. All epoxides used were greater than $99 \%$ pure. Butylene oxide and styrene oxide were vaporized in a heated distillation flask with a stream of dry nitrogen which was metered into the chamber inlet. For the propylene oxide exposures, a heated stainless steel cylinder covered with a glass fiber wick was placed in the chamber air inlet, and liquid propylene oxide was pumped onto the wick, from which it vaporized. Liquid ethylene oxide was vaporized in a stainless steel coil and metered into chamber air intakes. Chamber concentrations were monitored by gas chromatography at approximately 40-min intervals throughout exposure.

Slightly different experimental regimens were used for the studies with ethylene oxide and propylene oxide than for those with butylene oxide and styrene oxide. With ethylene oxide and propylene oxide only one exposure concentration was used, selected following preliminary probe studies. Two concentrations were used with butylene oxide and styrene oxide, selected on the basis of published acute toxicity data. The concentrations were selected with the objective of inducing measurable maternal toxicity but no mortality. In the experiments with ethylene oxide, propylene oxide, and butylene oxide the same concentration was used for the exposure of rabbits as was used for the rats, ie, 150 $\mathrm{ppm}\left(270 \mathrm{mg} / \mathrm{m}^{3}\right)$ of ethylene oxide, 500 $\mathrm{ppm}\left(1,188 \mathrm{mg} / \mathrm{m}^{3}\right)$ of propylene oxide, and 250 and $1,000 \mathrm{ppm}$ (737 \& $2,950 \mathrm{mg} / \mathrm{m}^{3}$, respectively) of butylene oxide. Due to the toxicity observed when rats were exposed to 100 and $300 \mathrm{ppm}$ (492 \& 1,474 $\mathrm{mg} / \mathrm{m}^{3}$, respectively) of styrene oxide, concentrations of 15 and $50 \mathrm{ppm}(74 \& 246$ $\mathrm{mg} / \mathrm{m}^{3}$, respectively) of styrene oxide were used for the rabbits. Daily exposures were for $7 \mathrm{~h}$ in all cases, but exposures were performed during different gestational stages in the ethylene oxide/propylene oxide versus butylene oxide/styrene oxide studies (tables 1 \& 2). During the 
Table 1. Rat exposure regimens in the epoxide reproduction studies.

\begin{tabular}{|c|c|c|c|c|c|}
\hline \multirow{3}{*}{ Group number } & \multicolumn{3}{|c|}{ Ethylene oxide and propylene oxide } & \multicolumn{2}{|c|}{ Butylene oxide and styrene oxide a } \\
\hline & \multirow{2}{*}{$\begin{array}{c}\text { Three weeks } \\
\text { before } \\
\text { breeding }\end{array}$} & \multicolumn{2}{|c|}{ Gestation days } & \multirow{2}{*}{$\begin{array}{c}\text { Three weeks } \\
\text { before } \\
\text { breeding }\end{array}$} & \multirow{2}{*}{$\begin{array}{c}\text { Gestation days } \\
1-19\end{array}$} \\
\hline & & $1-6$ & $7-16$ & & \\
\hline $\begin{array}{l}1 \\
2\end{array}$ & $\begin{array}{l}\text { Filtered air } \\
\text { Filtered air }\end{array}$ & $\begin{array}{l}\text { Filtered air } \\
\text { Filtered air }\end{array}$ & $\begin{array}{l}\text { Filtered air } \\
\text { Epoxide }\end{array}$ & $\begin{array}{l}\text { Filtered air } \\
\text { Filtered air }\end{array}$ & $\begin{array}{l}\text { Filtered air } \\
\text { Low epoxide } \\
\text { concentration }\end{array}$ \\
\hline 3 & Filtered air & Epoxide & Epoxide & $\begin{array}{l}\text { Low epoxide } \\
\text { concentration }\end{array}$ & $\begin{array}{l}\text { concentration } \\
\text { Filtered air }\end{array}$ \\
\hline 4 & Epoxide & Epoxide & Epoxide & Low epoxide & Low epoxide \\
\hline 5 & $\cdot$ & • & $\cdot$ & $\begin{array}{l}\text { concentration } \\
\text { Filtered air }\end{array}$ & $\begin{array}{l}\text { concentration } \\
\text { High epoxide }\end{array}$ \\
\hline 6 & • & $\cdot$ & - & High epoxide & $\begin{array}{l}\text { concentration } \\
\text { Filtered air }\end{array}$ \\
\hline 7 & • & - & - & $\begin{array}{l}\text { concentration } \\
\text { High epoxide } \\
\text { concentration }\end{array}$ & $\begin{array}{l}\text { High epoxide } \\
\text { concentration }\end{array}$ \\
\hline
\end{tabular}

a Only groups 1 through 4 completed the styrene oxide study.

Table 2. Rabbit exposure regimens in the epoxide reproduction studies.

\begin{tabular}{clll}
\hline Group Number & \multicolumn{2}{c}{$\begin{array}{c}\text { Ethylene oxide and propylene oxide } \\
\text { (gestation days) }\end{array}$} & $\begin{array}{c}\text { Butylene oxide and styrene oxide } \\
\text { (gestation days 1-24) }\end{array}$ \\
\cline { 2 - 4 } & $1-6$ & $7-19$ & Filtered air \\
1 & $\begin{array}{l}\text { Filtered air } \\
\text { Filtered air }\end{array}$ & $\begin{array}{l}\text { Filtered air } \\
\text { Epoxide } \\
\text { Epoxide }\end{array}$ & $\begin{array}{l}\text { Low epoxide concentration } \\
\text { High epoxide concentration }\end{array}$ \\
\hline
\end{tabular}

exposures food and water were withdrawn, but both were freely available at all other times. The animals were singly housed in stainless steel cages with wire mesh flooring and were sacrificed on day 21 (rats) or 30 (rabbits) of gestation (day 1 of gestation was the day sperm were detected in vaginal smears from rats and the day following the midafternoon artificial insemination of rabbits).

All the fetuses were examined for external defects. Then half were decapitated, and the heads were preserved in Bouin's fluid for internal examination by the technique of razor blade sectioning $(11,12)$. All the fetuses were examined for visceral defects by dissection under magnification $(8,10)$, and all the carcasses were then cleared and stained for skeletal examination (9). The only exception to this procedure was in the butylene oxide/ styrene oxide studies, when only half of the rat fetuses were examined by the Staples technique for visceral defects.

\section{Results}

\section{Ethylene oxide}

Exposure to $150 \mathrm{ppm}$ of ethylene oxide caused no mortality in nonpregnant or pregnant females of either species (table 3), but maternal rats showed toxic signs at necropsy (table 4). Body weight was reduced only in the rats exposed before and during gestation (group 4), but the spleen and kidney weights (both absolute and relative to body weight) were increased in all three ethylene oxide-exposed groups. Rabbits appeared to be unaffected by $150 \mathrm{ppm}$ of ethylene oxide (table 4 ).

Embryo and fetal toxicity (table 5) was evident in rat litters as a statistically significant increase in the incidence of resorptions in group 4. Fetal body weight and crown-rump length were reduced in all ethylene oxide-exposed groups. External, visceral, and skeletal examinations revealed no treatment-related effects 
other than an increased incidence of reduced skeletal ossification (primarily of the skull and sternebrae) in all ethylene oxide-exposed groups. No evidence of embryo or fetal toxicity or of developmental defects was detected in the ethylene

Table 3. Rat and rabbit mortality summary.

\begin{tabular}{|c|c|c|c|c|c|c|c|c|}
\hline & \multirow{2}{*}{$\begin{array}{l}\text { Ethylene } \\
\text { oxide } \\
\text { (150 ppm) }\end{array}$} & \multirow{2}{*}{$\begin{array}{c}\text { Propylene } \\
\text { oxide } \\
\text { (500 ppm) }\end{array}$} & \multicolumn{2}{|c|}{ Butylene oxide } & \multicolumn{4}{|c|}{ Styrene oxide } \\
\hline & & & 250 ppm & $1,000 \mathrm{ppm}$ & 15 ppm & $50 \mathrm{ppm}$ & 100 ppm & 300 ppm \\
\hline Rats & - & 一 & - & $\begin{array}{r}2 \% \\
(19 \mathrm{~d})\end{array}$ & • & $\cdot$ & $\begin{array}{l}16 \% \\
(19 \mathrm{~d})\end{array}$ & $\begin{array}{r}42 \% \\
(1 \mathrm{~d})\end{array}$ \\
\hline Rabbits & - & - & $\begin{array}{r}12 \% \\
(24 \mathrm{~d})\end{array}$ & $\begin{array}{r}58 \% \\
(24 \mathrm{~d})\end{array}$ & $\begin{array}{r}17 \% \\
(24 \mathrm{~d})\end{array}$ & $\begin{array}{l}79 \% \\
(24 \mathrm{~d})\end{array}$ & : & : \\
\hline
\end{tabular}

Table 4. Summary of organ and body weight changes occurring in the rats and rabbits. [Incr = statistically significant increase; decr = statistically significant decrease; (incr)? $=$ trend suggestive of an increase, but not statistically significant; (decr)? = trend suggestive of a decrease, but not statistically significant; ND = not determined; - magnitude nil; $:$ = category not applicablel

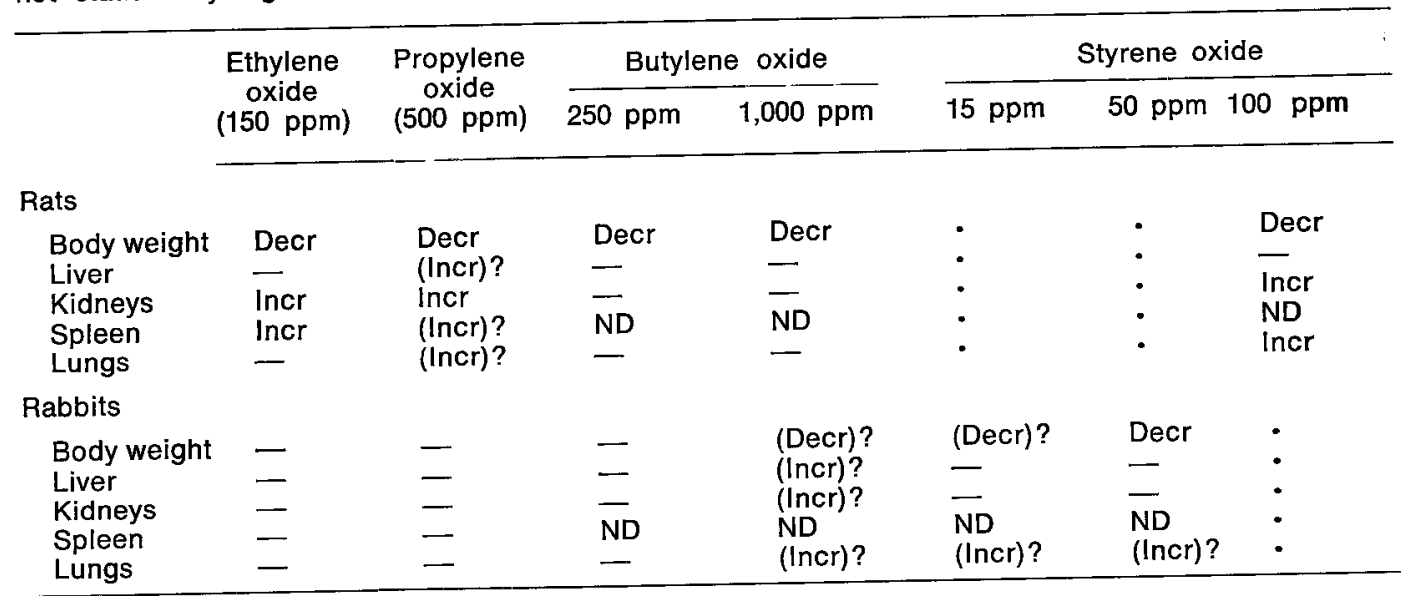

Table 5. Summary of the reproductive status of the rats. [Incr $=$ statistically significant increase; decr = statistically significant decrease; (decr)? = trend suggestive of a decrease, but not statistically significant; - = magnitude nil]

\begin{tabular}{|c|c|c|c|c|c|}
\hline \multirow[b]{3}{*}{ Pregnant $(\%)$} & \multirow{2}{*}{$\begin{array}{l}\text { Ethylene } \\
\text { oxide } \\
\text { (150 ppm) }\end{array}$} & \multirow{2}{*}{$\begin{array}{l}\text { Propylene } \\
\text { oxide } \\
\text { (500 ppm) }\end{array}$} & \multicolumn{2}{|c|}{ Butylene oxide } & \multirow{2}{*}{$\begin{array}{l}\text { Styrene } \\
\text { oxide } \\
\text { (100 ppm) }\end{array}$} \\
\hline & & & 250 ppm & 1,000 ppm & \\
\hline & 一 & 一 & - & - & Decr \\
\hline $\begin{array}{l}\text { Corpora lutea (N) } \\
\text { Implants (N) }\end{array}$ & (Decr)? & Decr & - & - & (Decr)? \\
\hline $\begin{array}{l}\text { Implants (N) } \\
\text { Resorptions (N) }\end{array}$ & $\overline{\text { Incr }}$ & Decr & - & - & - \\
\hline Live fetuses (N) & - & Decr & 一 & - & 一 \\
\hline $\begin{array}{l}\text { Fetal weight } \\
\text { Fetal length }\end{array}$ & $\begin{array}{l}\text { Decr } \\
\text { Decr }\end{array}$ & $\begin{array}{l}\text { Decr } \\
\text { Decr }\end{array}$ & - & - & $\begin{array}{l}\text { Decr } \\
\text { Decr }\end{array}$ \\
\hline $\begin{array}{l}\text { Skeletal alterations } \\
\text { Rib dysmorphology } \\
\text { Reduced ossification }\end{array}$ & Incr & $\begin{array}{l}\text { Incr } \\
\text { Incr }\end{array}$ & 二 & - & $\overline{\text { Incr }}$ \\
\hline
\end{tabular}


oxide-exposed rabbits (table 6).

\section{Propylene oxide}

Exposure to $500 \mathrm{ppm}$ of propylene oxide caused no mortality in nonpregnant or pregnant females of either species (table 3). Rats exposed to propylene oxide weighed consistently less than those exposed to filtered air (table 4), and a distinct reduction in the rate of body weight gain was obvious as groups 2 and 3 changed from filtered air to propylene oxide exposure. Relative lung, liver, kidney, and spleen weights were increased in the propylene oxide-exposed rats, particularly those exposed both before breeding and during gestation (group 4). However the three propylene oxide-exposed groups differed significantly from the controls only in the case of relative kidney weight. Other significant observations of the rats involved the numbers of corpora lutea, implants, and live fetuses (tables 5 \& 7 ). All three of these indices were significantly reduced $(p<0.01)$ for rats in group 4 , ie, those rats exposed to propylene oxide for three weeks before breeding, relative to the other propylene oxideexposed rats (groups 2 \& 3). Resorptions were increased for the rats in group 2 (exposed to propylene oxide on days $7-16$ of gestation), but not in rats of group 3 or 4. Rabbits appeared to be relatively unaffected by $500 \mathrm{ppm}$ of propylene oxide (table 4).

Several indices of embryo and fetal toxicity were significantly affected in the propylene oxide-exposed rats. Fetal body

Table 6. Summary of the reproductive status of the rabbits. [(Incr)? = trend suggestive of an increase, but not statistically significant; (decr)? = trend suggestive of a decrease, but not statistically significant; $-=$ magnitude nil]

\begin{tabular}{|c|c|c|c|c|c|c|}
\hline & \multirow{2}{*}{$\begin{array}{l}\text { Ethylene } \\
\text { oxide } \\
(150 \mathrm{ppm})\end{array}$} & \multirow{2}{*}{$\begin{array}{l}\text { Propylene } \\
\text { oxide } \\
(500 \mathrm{ppm})\end{array}$} & \multicolumn{2}{|c|}{ Butylene oxide } & \multicolumn{2}{|c|}{$\begin{array}{c}\text { Styrene } \\
\text { oxide }\end{array}$} \\
\hline & & & $250 \mathrm{ppm}$ & $1,000 \mathrm{ppm}$ & $15 \mathrm{ppm}$ & $50 \mathrm{ppm}$ \\
\hline Pregnant $(\%)$ & - & - & - & - & - & - \\
\hline $\begin{array}{l}\text { Corpora lutea (N) } \\
\text { Implants (N) } \\
\text { Resorptions (N) } \\
\text { Live fetuses (N) }\end{array}$ & $\begin{array}{l}- \\
z\end{array}$ & $\begin{array}{l}- \\
z\end{array}$ & $\begin{array}{l}- \\
-\end{array}$ & $\begin{array}{l}- \\
\overline{-}\end{array}$ & $\begin{array}{l}- \\
\text { (Decr)? } \\
\text { (Incr)? } \\
\text { (Decr)? }\end{array}$ & $\begin{array}{l}\text { - } \\
\text { (Decr)? } \\
\text { (lncr)? } \\
\text { (Decr)? }\end{array}$ \\
\hline $\begin{array}{l}\text { Fetal weight } \\
\text { Fetal length }\end{array}$ & - & - & - & - & $\begin{array}{l}\text { (Decr)? } \\
\text { (Decr)? }\end{array}$ & $\begin{array}{l}\text { (Decr)? } \\
\text { (Decr)? }\end{array}$ \\
\hline $\begin{array}{l}\text { Skeletal alterations } \\
\text { Rib dysmorphology } \\
\text { Reduced ossification }\end{array}$ & - & 二 & - & - & 二 & 二 \\
\hline
\end{tabular}

Table 7. Average number of corpora lutea in pregnant rats and total group sizes in the ethylene oxide and propylene oxide studies.

\begin{tabular}{|c|c|c|c|c|c|c|c|c|c|c|c|c|}
\hline & \multirow{3}{*}{\multicolumn{3}{|c|}{$\begin{array}{l}\text { Filtered air } \\
\text { exposure (preges- } \\
\text { tation + gestation } \\
\text { days } 1-16 \text { ) }\end{array}$}} & \multicolumn{6}{|c|}{ Ethylene (150 } & \multirow{3}{*}{\multicolumn{3}{|c|}{$\begin{array}{c}\text { (500 } \mathrm{ppm}) \\
\begin{array}{c}\text { Pregestation } \\
+ \text { gestation } \\
\text { days } 1-16\end{array} \\
\end{array}$}} \\
\hline & & & & \multicolumn{6}{|c|}{ Gestation days } & & & \\
\hline & & & & \multicolumn{3}{|c|}{$7-16$} & \multicolumn{3}{|c|}{$1-16$} & & & \\
\hline & \multirow{2}{*}{$\begin{array}{l}\text { Group } \\
\text { size }\end{array}$} & \multicolumn{2}{|c|}{$\begin{array}{l}\text { Corpora } \\
\text { lutea }\end{array}$} & \multirow{2}{*}{$\begin{array}{l}\text { Group } \\
\text { size }\end{array}$} & \multicolumn{2}{|c|}{$\begin{array}{c}\text { Corpora } \\
\text { lutea }\end{array}$} & \multirow{2}{*}{$\begin{array}{l}\text { Group } \\
\text { size }\end{array}$} & \multicolumn{2}{|c|}{$\begin{array}{l}\text { Corpora } \\
\text { Iutea }\end{array}$} & \multirow{2}{*}{$\begin{array}{l}\text { Group } \\
\text { size }\end{array}$} & \multicolumn{2}{|c|}{$\begin{array}{c}\text { Corpora } \\
\text { lutea }\end{array}$} \\
\hline & & Mean & $\mathrm{SD}$ & & Mean & $S D$ & & Mean & SD & & Mean & $S D$ \\
\hline $\begin{array}{l}\text { Ethylene oxide } \\
\text { Propylene oxide }\end{array}$ & $\begin{array}{l}41 \\
46\end{array}$ & $\begin{array}{l}15.4 \\
15.4\end{array}$ & $\begin{array}{l}2.1 \\
3.1\end{array}$ & $\begin{array}{l}41 \\
44\end{array}$ & $\begin{array}{l}15.2 \\
15.6\end{array}$ & $\begin{array}{l}2.9 \\
3.3\end{array}$ & $\begin{array}{l}41 \\
41\end{array}$ & $\begin{array}{l}15.4 \\
15.4\end{array}$ & $\begin{array}{l}2.8 \\
2.2\end{array}$ & $\begin{array}{l}39 \\
43\end{array}$ & $\begin{array}{l}14.6 \\
13.8\end{array}$ & $\begin{array}{l}3.1 \\
3.0\end{array}$ \\
\hline
\end{tabular}

* Significantly less than the other propylene oxide-exposed groups ( $p<0.01$ ). 
weight and crown-rump length were significantly reduced in all propylene oxide-exposed groups (table 5). External, visceral, and skeletal examinations of rat fetuses revealed no significant alterations in the developmental process except for an increased incidence of rib dysmorphology (primarily wavy ribs) and reduced skeletal ossification (primarily of the vertebrae and ribs) in the propylene oxideexposed litters. No evidence of embryo or fetal toxicity or of developmental defects was detected in the propylene oxideexposed rabbits (table 6).

\section{Butylene oxide}

Of the rats exposed to $1,000 \mathrm{ppm}$ of butylene oxide, 1 of 106 died before breeding, and 1 of 80 died during gestational exposure (table 3). A significant reduction in rat body weight was noted at both exposure levels (table 4). Persisting maternal toxicity among the rats was suggested by the fact that weight gain during pregnancy was reduced in both groups that were exposed to butylene oxide before breeding and to filtered air during gestation (groups 3 \& 6 , table 1), as well as in rats exposed to butylene oxide during gestation. In an earlier summary of results (3), rat maternal toxicity was erroneously tabulated as "absent" (table 5 in that 1981 publication) rather than "present." The corpus luteum counts of the rats were not affected by butylene oxide exposure (table 8 ).

Rabbits on the other hand were much more severely affected by exposure to butylene oxide at 250 and $1,000 \mathrm{ppm}$ (table 3). Mortality was significantly increased at both concentrations. Suppurative pneumonia was noted in those rabbits that died during exposure. There were no deaths of rabbits exposed to filtered air. Despite the increased mortality at both exposure levels, there was not a statistically significant change in the body weight of surviving rabbits (table 4). The day 30 body weights were markedly reduced for the two pregnant survivors of $1,000 \mathrm{ppm}$ exposure [3.0 vs 3.5 (0.4 SD) kg for the controls], but the survivors of 250 ppm exposure were equal in weight to the control rabbits.

Despite the maternal toxicity noted for rats (reduced body weight), there was no evidence of embryo or fetal toxicity (table 5 ), and no evidence suggestive of developmental toxicity was noted in the external, visceral, and skeletal examinations. There was significant maternal toxicity for the rabbits at $250 \mathrm{ppm}$ of butylene oxide, although there was no suggestion of embryo or fetal toxicity or of developmental toxicity. For the rabbits suggestive evidence of embryo and fetal toxicity was seen in the two litters from the $1,000 \mathrm{ppm}$ group (table 6 ), but statistical significance was not demonstrated due to the very small group size.

\section{Styrene oxide}

Styrene oxide was unexpectedly toxic for rats at both 100 and $300 \mathrm{ppm}$ (table 3 ). Some rats died during the first $7-\mathrm{h}$ exposure at $300 \mathrm{ppm}$, and consequently no further exposures were made at that concentration. Mortality continued during the next $2 \mathrm{~d}$. A total of $42 \%$ died within this $3-d$ period, and the survivors were

Table 8. Average number of corpora lutea in pregant rats and total group sizes in the butylene oxide study.

\begin{tabular}{|c|c|c|c|c|c|c|c|c|c|}
\hline \multirow{5}{*}{$\begin{array}{l}\text { Pregestation } \\
\text { exposure }\end{array}$} & \multicolumn{9}{|c|}{ Gestation exposure (dg 1-19) } \\
\hline & \multirow{2}{*}{\multicolumn{3}{|c|}{ Filtered air }} & \multicolumn{6}{|c|}{ Butylene oxide } \\
\hline & & & & \multicolumn{3}{|c|}{$250 \mathrm{ppm}$} & \multicolumn{3}{|c|}{ 1,000 ppm } \\
\hline & \multirow{2}{*}{$\begin{array}{l}\text { Group } \\
\text { size }\end{array}$} & \multicolumn{2}{|c|}{ Corpora lutea } & \multirow{2}{*}{$\begin{array}{l}\text { Group } \\
\text { size }\end{array}$} & \multicolumn{2}{|c|}{ Corpora lutea } & \multirow{2}{*}{$\begin{array}{l}\text { Group } \\
\text { size }\end{array}$} & \multicolumn{2}{|c|}{ Corpora lutea } \\
\hline & & $\overline{\text { Mean }}$ & $\overline{\mathrm{SD}}$ & & Mean & $\mathrm{SD}$ & & Mean & SD \\
\hline $\begin{array}{l}\text { Filtered air } \\
\text { Butylene oxide }\end{array}$ & 35 & 17.1 & 3.9 & 32 & 15.8 & 3.2 & 28 & 16.4 & 4.8 \\
\hline $\begin{array}{l}\text { Butylene oxide } \\
250 \mathrm{ppm} \\
1,000 \mathrm{ppm}\end{array}$ & $\begin{array}{l}33 \\
31\end{array}$ & $\begin{array}{l}15.9 \\
15.3\end{array}$ & $\begin{array}{l}3.6 \\
3.0\end{array}$ & 36 & 16.0 & $\begin{array}{c}4.2 \\
\cdot\end{array}$ & i & 15.2 & $\dot{2.4}$ \\
\hline
\end{tabular}


killed at that time. Exposures were completed as planned for the 100-ppm level, with an overall mortality of approximately $16 \%$. The body weight of the rats exposed to $100 \mathrm{ppm}$ of styrene oxide was significantly reduced (table 4), while the lung and kidney weights were significantly increased in relation to body weight.

Rabbits were exposed at only 15 and $50 \mathrm{ppm}$, but maternal toxicity was similar to that seen for rats (table 3). Maternal body weight was reduced for the styrene oxide-exposed rabbits, but other than an increase in lung weight, systematic organ weight changes were not noted (table 4).

Embryo and fetal toxicity was evident in rats exposed to $100 \mathrm{ppm}$ of styrene oxide during gestation (table 5). The most striking change was a significant decrease in the fraction of gestationally-exposed sperm-positive rats which became pregnant. Since corpora lutea, but no implantation sites, were found in the nonpregnant animals, it is inferred that this finding represents preimplantation loss of fertilized ova or blastocysts. In addition to a reduction in fetal body weight and length, there was a reduction in skeletal ossification (primarily of the skull and sternebrae) of styrene oxide-exposed litters. However, there was no evidence of an increased incidence of frank structural malformations. The evaluation of the rabbits did not reveal statistically significant evidence of embryo or fetal toxicity at $15 \mathrm{ppm}$ (table 6), but in the four surviving litters exposed to $50 \mathrm{ppm}$ of styrene oxide there were several indices suggestive of toxic effects. There were no significant alterations observed in the external, visceral, or skeletal examinations of rabbit fetuses.

Although the groups did not differ statistically, there was a reduction in the number of corpora lutea in rats exposed to $100 \mathrm{ppm}$ of styrene oxide before breeding [12.4 (SD 1.9) in group 3 and 12.2 (SD 0.8) in group 4] relative to those exposed to filtered air before breeding [14.0 (SD 3.2) in group 1 and 14.2 (SD 3.0) in group 2] (table 9).

\section{Discussion}

A comparison of these results is necessarily complex due to the breadth of measures and the slight differences in experimental regimens employed. Nevertheless, several general conclusions can be reached, and consistent patterns are evident. First, none of these epoxides were more lethal in pregnant rats than in nonpregnant rats. There were no apparent differences between the degree of reduced body weight gain or food consumption among pregnant rats versus nonpregnant rats. Although the details were not presented in this communication, maternal body weight gain reductions were invariably accompanied by reduced food consumption. In general, rats were affected more than rabbits by ethylene oxide and propylene oxide exposure, while rabbits were affected more by butylene oxide and styrene oxide. The species difference was the most prominent for styrene oxide, for which the mortality of rabbits at $15 \mathrm{ppm}$ approximated that of rats exposed to $100 \mathrm{ppm}$. Organ and body weights were affected by exposure to ethylene oxide and propylene oxide in rats but not in rabbits.

Some investigators feel that, in experimental studies, fetal toxicity invariably precedes or is more severe than maternal toxicity, and that maternally toxic doses should be avoided on the assumption that they will necessarily lead

Table 9. Average number of corpora lutea in pregnant rats and total group sizes in the styrene oxide study.

\begin{tabular}{|c|c|c|c|c|c|c|}
\hline \multirow{4}{*}{ Pregestation exposure } & \multicolumn{6}{|c|}{ Gestation exposure } \\
\hline & \multicolumn{3}{|c|}{ Filtered air } & \multicolumn{3}{|c|}{ Styrene oxide (100 ppm) } \\
\hline & \multirow{2}{*}{$\begin{array}{l}\text { Group } \\
\text { size }\end{array}$} & \multicolumn{2}{|c|}{ Corpora lutea } & \multirow{2}{*}{$\begin{array}{l}\text { Group } \\
\text { size }\end{array}$} & \multicolumn{2}{|c|}{ Corpora lutea } \\
\hline & & Mean & SD & & Mean & SD \\
\hline $\begin{array}{l}\text { Filtered air } \\
\text { Styrene oxide (100 ppm) }\end{array}$ & $\begin{array}{l}34 \\
28\end{array}$ & $\begin{array}{l}14.0 \\
12.4\end{array}$ & $\begin{array}{l}3.2 \\
1.9\end{array}$ & $\begin{array}{r}12 \\
5\end{array}$ & $\begin{array}{l}14.2 \\
12.2\end{array}$ & $\begin{array}{l}3.0 \\
0.8\end{array}$ \\
\hline
\end{tabular}


to fetal toxicity or developmental defects. In the present studies, developmental effects were minimal in rabbits exposed to the lower concentrations of butylene oxide and styrene oxide even though these levels caused $12 \% \quad(250 \mathrm{ppm}$ of butylene oxide) and $17 \%$ (15 ppm of styrene oxide) mortality in adults. The reductions in the fetal body weight and length of rabbits were not statistically significant at these concentrations, and there was no increase in pre- or postimplantation death. Neither was there an increase in the incidence of fetal malformations or minor variations such as reduced skeletal ossification. These results illustrate that some chemicals may not severely affect the conceptus despite marked maternal toxicity. Efforts to identify potentially hazardous chemicals (particularly in the case of those for which exposure may be chronic) may be strengthened by the inclusion of maternally toxic exposures in the test protocol to insure a maximal challenge to the developmental processes. As illustrated by these results, inclusion of a maternally toxic level does not necessarily mean that every chemical so tested will be reported as developmentally toxic. Moreover, such findings may provide an added degree of confidence in setting permissible exposure limits. For chemicals of this kind, levels which are safe for the pregnant worker will also be safe for her conceptus.

The results reported in this communication are consistent with those of the study by Snellings et al (7), in which fetotoxic but not teratogenic effects were seen in rats exposed to $100 \mathrm{ppm}$ of ethylene oxide. In contrast LaBorde \& Kimmel (5) found, at doses that were not maternally toxic, that intravenously injected ethylene oxide induced a significant incidence of skeletal malformations in mice. The possibility of a species difference cannot be ruled out since mice have not been tested by inhalation exposure or rats and rabbits by intravenous injection, but this explanation seems unlikely. It thus appears likely that teratogenic doses of ethylene oxide cannot readily be delivered to the fetus by repeated exposure of the pregnant female to ethylene oxide vapor. It may be speculated that the differences in findings relate to the differences in systemic distribution in the dam or to ethylene oxide concentrations attained in the conceptus during sensitive stages of gestation. Systemic concentrations resembling those following intravenous injection might result from brief exposures to extremely high vapor concentrations, but this possibility has not been investigated. Similarly, propylene oxide, butylene oxide, and styrene oxide were not teratogenic in this inhalation study, but if these epoxides are used in applications that may result in their intravenous injection into humans, as is the case with ethylene oxide, that route should be tested. Such testing would be particularly important for propylene oxide since maternally toxic exposures in these studies did induce minor skeletal anomalies in rat fetuses.

Another finding reported by Snellings et al (7) may be related to an unexpected observation by us. Snellings et al reported that in a reproduction study female rats exposed to $100 \mathrm{ppm}$ ethylene oxide for 12 weeks before breeding had a longer gestation period, reduced fertility index, and fewer pups. The time to parturition was not observed in the present studies, and exposure for three weeks before breeding did not alter the proportion of females that became pregnant. However exposure to styrene oxide from day 1 of gestation significantly reduced the proportion of sperm-positive rats that became pregnant, and exposure to propylene oxide for three weeks before breeding significantly reduced the numbers of corpora lutea, implants, and live fetuses (tables 5 \& 7 ). Similarly, rats exposed to ethylene oxide (table 7) and styrene oxide (table 9) before breeding had small (and not statistically significant) reductions in corpora lutea. Butylene oxide exposure was clearly without effect (table 8). The results of this abbreviated form of reproduction testing illustrate the value of exposing nonpregnant females to environmental or industrial chemicals prior to teratologic testing as a convenient and cost-effective means of detecting chemicals with a potential for reproductive toxicity. These data suggest that prolonged exposure to propylene oxide, and possibly ethylene oxide and styrene oxide, may reduce female reproductive potential by impairing 
oocyte maturation or ovulation. Several mechanisms might underlie such an effect, such as direct action at the level of the pituitary or ovary or an indirect effect mediated through epoxide binding of circulating hormones. In addition exposure to styrene oxide appears to interfere with implantation. These observations warrant more-detailed studies designed to confirm the effect and investigate the mechanisms of action.

\section{References}

1. Ehrenberg L, Hussain S. Genetic toxicity of some important epoxides. Mutat res 86 (1981) $1-113$.

2. Hackett PL, Brown MG, Buschbom RL, Clark ML, Miller RA, Music RL, Rowe SC, Schirmer RL, Sikov MR. Teratogenic study of ethylene and propylene oxide and n-butyl acetate. Battelle Pacific Northwest Laboratories, Richland, WA 1982. (Final report to the National Institute for Occupational Safety and Health, contract no 210-81-0013, May 1982).

3. Hardin BD, Bond GP, Sikov MR, Andrew FD, Beliles RP, Niemeier RW. Testing of selected workplace chemicals for teratogenic potential. Scand $j$ work environ health 7 (1981): suppl 4, 66-75.

4. International Agency for Research on Cancer. Cadmium, nickel, some epoxides, miscellaneous industrial chemicals and general considerations on volatile anaesthetics. Lyon 1976, pp 157-167, 191-199 \& 201-208.

5. LaBorde JB, Kimmel CA. The teratogenicity of ethylene oxide administered intra- venously to mice. Toxicol appl pharmacol 56 (1980) 16-22.

6. Sikov MR, Cannon WC, Carr DB, Miller RA, Montgomery LF, Phelps DW. Teratologic assessment of butylene oxide, styrene oxide, and methyl bromide. US Department of Health and Human Services, Public Health Service, Centers for Disease Control, National Institute for Occupational Safety and Health. Cincinnati, OH 1981. 76 p. (DHHS (NIOSH) publication no $81-$ 124).

7. Snellings WM, Zelenak JP, Weil CS. Effects on reproduction in Fischer 344 rats exposed to ethylene oxide by inhalation for one generation. Toxicol appl pharmacol 63 (1982) 382-388.

8. Staples RE. Detection of visceral alterations in mammalian fetuses. Teratology 9 (1974) $37-38$.

9. Staples RE, Schnell VL. Refinements in rapid clearing technic in the $\mathrm{KOH}-$ alizarin red $\mathbf{S}$ method for fetal bone. Stain technol 39 (1964) 62-63.

10. Sterz $H$. Routine examination of rat and rabbit fetuses for malformations of internal organs - Combination of Barrow's and Wilson's methods. In: Neubert D, Merker H-J, Kwasigroch TE, ed. Methods in prenatal toxicology. Georg Thieme Publishers, Stuttgart 1977, pp 113-125.

11. van Julsingha EB, Bennett CG. A dissecting procedure for the detection of anomalies in the rabbit foetal head. In: Neubert $\mathrm{D}$, Merker $\mathrm{H}-\mathrm{J}$, Kwasigroch TE, ed. Methods in prenatal toxicology, Georg Thieme Publishers, Stuttgart 1977, pp $126-144$.

12. Wilson JG. Methods for administering agents and detecting malformations in experimental animals. In: Wilson JG, Warkany $J$, ed. Teratology principles and techniques. University of Chicago Press, Chicago, IL 1965, pp 262-277. 